\title{
THE SEX POLICE COMETH: LAWYER-CLIENT SEXUAL RELATIONSHIPS
}

\author{
DANIEL FILIPOVIC
}

The fiduciary asper' of a lanver-cliem relationship) is capable of being undermined if a lanyer and his client become sexwally involved. Curremly. the various law society regulations in Canada are mo brocad (I) property adelress the problem of unbecoming comaluct arising in situeations of laniverclient sexual relouiomship.s. Samotions impesed in cases of lanyer misconduct in this area are ans lenient and condal lead II a Irivialisation of this problem by failing to acknom/edge the potemtal harm that exists and by discouraging future complainants from raking action. Sexual involvement is proscribed

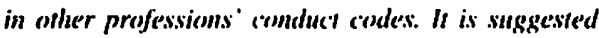
the legal profession could henefit from an addision to) its consuluct codes of a provision proscribing lanyerclient sexual relationships.

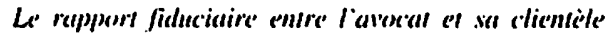
pestl citre compromis si les deux intéressies om entre cux des relations sexuelles. Actucllement. les différenss règlements des associations projessiommelles som irop généraux pour permeture de traiter du problème de combluite qui découle de as senre de sinution. Less mesures viscunt à sanctiommer les cas de combluite incomvenamte somt trop) indulgentes. Elles pourraient résulter on un certaine' discrédit du problème en ne recommaisisam pas lo danger existam et en dissuadant ainsi les plaignantes d'intenter des pourswites. Le code de conduite de nombreases autres professioms proscrit les relations. de r'fle' nuturs. On suggère que' le Burreou aurait imeirit à inclure dans som code de conduite une

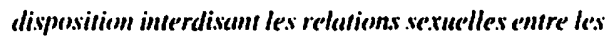
arocuss en leur clientèle.

\section{TABLE OF CONTENTS}

1. INTRODUCTION ..................... 391

II. LAWYER-CLIENT RELATIONSHIP IS BASED

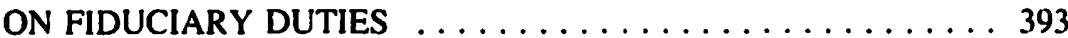

III. LAWYER-CLIENT SEXUAL INVOLVEMENT

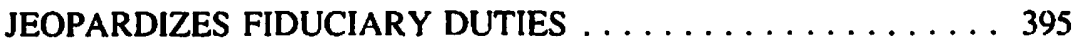

IV. INEFFECTIVE LEGISLATIVE LANGUAGE AND

PROFESSIONAL CONDUCT COMMENTARIES . . . . . . . . 397

A. INEFFECTIVE SANCTIONS IMPOSED

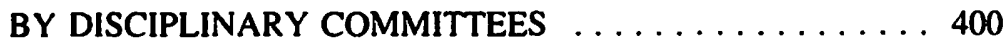

V. REGULATION OF SEXUAL INVOLVEMENT

WITHIN FIDUCIARY RELATIONSHIPS $\ldots \ldots \ldots \ldots \ldots \ldots$

VI. PREVENTATIVE SUGGESTIONS $\ldots \ldots \ldots \ldots \ldots \ldots \ldots \ldots 406$

VII. CONCLUSION ....................... 409

\section{INTRODUCTION}

Choices in sexual associations are generally not thought of as legally restricted. Normally this is a decision which is freely taken and governed only by one's own discretion and by the consent of another adult. Nonetheless, this paper discusses why such

Articling student with Filipovic, Brothers \& Conway. Thunder Bay, Ontario. The author wishes to thank Ekaterini Nikolarea for helpful comments on carlier drafts. 
a restriction on sexual relations between a male lawyer and his client would be necessary.'

One can understand better the need for such a restriction if one considers how many lawyers in recent years in the United States and Canada have been disciplined for failing to control their sexual attractions to clients. The increased number of disciplinary actions suggests that there are many unreported instances. The following newspaper clipping suggests a typical attitude among lawyers towards lawyer-client sexual relationships that is, a topic upon which lawyers would rather not elaborate:

The British weckly newspaper The Lawyer offers advice on "practice management problems.":

Q. I am a 32-ycar-old assistant solicitor working for a medium-sized gencral practice, specializing mainly in litigation. Last month I had an appointment with an established clicnt, an attractive blonde divonce who had purchased a defective vacuum cleaner from a local shopkeeper. who had refused to replace it or refund her money. As I tonk down the details I could not help noticing that her dress was extremely low-cut and she kept giving me long lingering looks. Our eyes met and within seconds we werc making passionate love on my desk. I have met her un scveral subsequent exceasions, when the same thing happened. I am married with threc children. What should I do?

A. Your elient should be ahle to ublain redress under s.13 or 14 of the Sale of Goxds Act 1979. provided it can be established that the goods were not of merchantable quality or fit for the purpose for which they were sold. Legal Aid will probably not be available owing to the small amount of the claim.'

The second part of this paper outlines the fiduciary nature of the lawyer-client professional relationship. The third part attempts to show, through Canadian and American cases, reports and articles, how lawyer-client sexual relationships can easily alter the lawyer's priority of interests and obligations, cause a lawyer to lose his objectivity and abuse what is considered the pith of his professional relationship: the trust between him and his client. Part four of this paper discusses the ineffectiveness of the legislative language, professional conduct rules and commentaries and use of sanctions imposed by the disciplinary committees to address the problem of lawyer-client sexual relationships. The fifth part of this paper discusses how sexual involvement is regulated within other specific fiduciary relationships. The sixth and final part of this paper, makes suggestions on how to prevent the problem from escalating without recommending a total prohibition on lawyer-client sexual involvement.

The reason I take this perspective and fixcus on the male lawycr's conduct is because. after an extensive perusal of the cases involving breaches of professional conduct as a result of lawyer-client sexual relationships, it is conspicuous that the offending lawyer is primarily male. 


\section{LAWYER-CLIENT RELATIONSHIP IS BASED ON FIDUCIARY PRINCIPLES}

In general it is recognized that a lawyer and client through the retainer enter an agency relationship in which the lawyer is the agent and the client is the principal. ${ }^{3}$ The lawyer is expected to provide certainty for problems that may be uncertain, to neutralize his passions in order to avoid any conflict of interest with his client's interests and to provide a high standard of professional performance. As a general rule it is assumed that the client trustingly and passively delegates responsibility for decisions to the professional. ${ }^{4}$ Therefore, what is created from this agency is a relationship of trust between the lawyer and client, otherwise called a fiduciary relationship. ${ }^{5}$ The trust in a fiduciary relationship imposes on the lawyer an ethical duty to keep client communications confidential. The confidentiality and fiduciary nature of the relationship is breached when confidential information is used by the lawyer to benefit himself, third parties or used to his client's disadvantage." As stated in LAC Minerals Ltd. v. International Corona, a breach of confidence consists of establishing first, that the information conveyed was confidential; second, that the information conveyed was communicated in confidence; and lastly, that the information was misused by the party to whom it was communicated.

From a client's perspective in divorce cases, it is casy to grasp the importance of the lawyer's fiduciary duty to his client. A woman seeking a divorce or advice on marital problems is often in a vulnerable, emotionally confused state and in need of support, concern and professional care on her behalf from a lawyer. Therefore, the client must prima facie entrust the lawyer with personal and intimate information without sufficient knowledge to evaluate the quality of the lawyer's performance or even to know whether the lawyer should be trusted. Thus combining the client's need to trust the lawyer with her inability to judge the lawyer creates a lawyer-client relationship which may make the client intellectually and emotionally dependent upon her lawyer. ${ }^{8}$ In a situation such as this, a divorce lawyer should understand the emotional state of a divorce client and be

Scherer v. Paletra. |1966| 2 O.R. 524 (Ont. C.A.).

D.E. Rosenthal. Luwyer and Cliemt: Who's in Charge? (New York: Russell Sage Foundation, 1974) at 14.3 .

Frame v. Smith. |1987| 2 S.C.R. 99. Wilson J. stated at page 136:

Relationships in which a fiduciary obligation have been imposed scem in possess three general characteristic:s:

1. The fiduciary has scope for the exercise of some discretion or power.

2. The fiduciary can uniluterally exercise that power or discretion so as to affect the beneficiary's legal or practical interests.

3. The beneficiary is peculiarly vulnerable to or at the mercy of the fiduciary holding the discretion or power.

These three characteristics were referred to with approval by Supinka J. in LAC Mineruls Ldd. v. Internationul Corrona (1989). 61 D.L.R. (4th) 14 at 63 (S.C.C.).

The Canadian Bar Association. 1987 Code of Professiomal Conduct (Otawa: The Canadian Bar Association, 1987) Chapter IV. Commentary 5.

LAC Minerals, surpa note 5 at 35.

L. Dubin, "Sex and the Divorce Lawyer: Is the Client Otr Limits?" (1987-88) I Georgetown J.L.E. 585 at 591 . 
aware of a process called "transference." Dr. Watson. a professor of law and psychiatry at the University of Michigan, suggests that the result is a situation that is casily exploited and any sexual involvement simply intensifies the client's dependency:"

Due to the psychological tendency on the part of the client to invest the counsellor with all sorts of power. authority and a niarly magical belief in their helpfulness, there will also be a powerful tendency to bcstow affection. These feelings largely are unrelated to truly personal involvement, and are mosily a function of the relationship itself. Thereforc, for a lawyer to take advantage of them would be quitc as unethical as making personal use of the client's money or property which had been entrusted to him in the coursc of carrying out the professional role.

In Canada, the Law Society of each province has incorporated the ideal of fiduciary principles into rules of professional conduct by imposing standards of acceptable conduct on one party [the lawyer| to a relationship for the benefit of the other [the client]. By this method the former has a responsibility for the preservation of the latter's interests. "The provincial codes of professional conduct, most of which were modelled after the Professional Conduct Code published by the Canadian Bar Association (CBA). ${ }^{12}$ explicitly and implicitly establish the obligatory fiduciary duties and the spirit of ethical responsibilities of the lawyer to his client, to the court and to the public.

In its handbook on professional conduct, the CBA outlines ethical responsibilities and duties of a lawyer that potentially could be construed to directly and indirectly impact on the lawyer-client sexual relationship. One duty is the lawyer's duty to his client to provide competent performance of legal services in a conscientious, diligent, loyal and efficient manner. A second duty is to hold in strict confidence all information acquired in the course of the professional relationship concerning the business and affairs of his client and not to divulge such information unless authorized by the client or required by law. Third, the duty of the lawyer is not to use client confidential information to benefit himself, third parties or used to his client's disadvantage. Fourth, the duty to keep the client fully informed by being candid and honest when advising him. Fifth, the lawyer owes a duty not to accept employment from the client if his loyalty to or professional judgment on behalf of his/her client will be affected adversely duc his own financial, business, property or personal interests. Sixth, the lawyer has to withdraw his services where, among many reasons, it becomes clear that his continued employment will involve him in a breach of

A. Freedman. H. Kaplan and B. Saddock. Modem Symopsis. Comprehensive Textbook of Psychioury // (Baltimore: Williams \& Wilkins, 1976). Transference refers to the process by which a person unconsciously projects feclings, uttributes and wishes which originally were linked with important people in one's early life onto others. Thus a lawycr may come to possess certain attractive or undesirable traits that stem more from the client's unconscious needs than from the client's accurate perceptions of reality. Hence. the basis for the client's altraction may be attributed to the power or saviour type function the lawyer is to serve rather than attributable the lawyer as a person. This concept of transference can operate in reverse [cross Iransferencel with respect to the lawyer:s perceptions of the client. Association. 1987). 
the professional conduct rules. Seventh, the lawyer has a responsibility to discharge his duties to his client, the court, the public and other members of the profession with integrity and in a manner that will encourage public respect for the administration of justice. Finally, the lawyer should observe the rules of professional conduct to the letter as well as in spirit to avoid conduct unbecoming of lawyers as well as conduct giving the appearance of impropriety.

\section{LAWYER-CLIENT SEXUAL INVOLVEMENT JEOPARDIZES FIDUCIARY DUTIES}

Under normal circumstances, a lawyer can face a number of conflicts of interests depending upon the variety of clients for whom he can act. Yet, these circumstances can become further complicated once he is engaged sexually with his client. Canadian and American case law provide numerous examples of lawyers abusing their position of power to coerce sexual participation, breaching their fiduciary duties and misusing confidential information for personal benefit as a result of sexual involvement with their clients.

In a number of American cases it has been held that to assault or coerce clients into sexual involvement is generally accepted as conduct unbecoming of a lawyer. In In re: Howard. ${ }^{13}$ the court held that a lawyer accepting sexual favours from clients, who were prostitutes, in lieu of financial payment is conduct unbecoming of a lawyer. As a disciplinary sanction the lawyer was simply reprimanded. In In re: Adams, ${ }^{14}$ a female client hired a lawyer to represent her in divorce proceedings. When she came into the office to pay. the lawyer grabbed her and began kissing her and lifted her blouse. The court held that this was illegal conduct involving moral turpitude, reflecting the lawyer's inability to conduct himself in a manner becoming a lawyer, as he sought to exploit the trust inherent in lawyer-client relationships for his personal plcasure. As disciplinary sanction, the lawyer received nothing more than a public reprimand. In In re: Matter of Liebowitz the Supreme Court of New Jersey publicly reprimanded an attorney for sexual contact with his pro bono female client.' In agreeing with the disciplinary committee's ruling, the court did not accept the defence that the client's participation was voluntary because it could reasonably be inferred that a failure to submit to the lawyer's desires would adversely impact on her legal representation. This suggests not only that the attorney's conduct was unbecoming of a professional, but also that the attorney may breach his obligation of diligently tackling the client's legal interest with the proper zeal and competence expected.

Similar to the preceding decisions in the United States, the disciplinary committee of the Law Society of Upper Canada, in a recent decision, ruled that Mr. Coccimiglio's conduct was unbecoming a lawyer. ${ }^{16}$ Upon being retained for divorce proceedings in November 1988, Mr. Coccimiglio went to the client's home to talk about the case. in 
particular about his client's sexual relationship with her husband. During that discussion Mr. Coccimiglio grabbed her breast and tried to pick her up by grabbing around her thighs and buttock. What is interesting in this case is that Mr. Coccimiglio had allegedly sexually assaulted another female client in his office almost two years before, in January 1987, but due to a technicality the charge was stayed. In the second assault the court convicted Mr. Coccimiglio of sexual assault, thus impliedly agreeing with the Law Society's discipline of twelve-month suspension, because the client was "in the position of vulnerability" and that "the violation of that trust by a solicitor is an extremely serious matter."

The above three cases, both in the United States and Canada, manifest how the unbecoming conduct undermines the integrity of the legal profession. Yet, even when the client is not assaulted or coerced into sexual involvement with the lawyer, the female client's legal interests can still be harmed or prejudiced in other ways as a result of a sexual relationship with her lawyer. The following cases illustrate the unpredictable cffect that a lawyer-client sexual relationship has on a client's as well as a lawyer's interests.

The following American cases show the unpredictable effects a lawyer-client sexual relationship can have on the client's interest. In the divorce trial In re: Lehr, ${ }^{17}$ the trial judge awarded custody to the father despite evidence that the father was seriously involved in substance abuse and spent little time with the child, while on the other hand evidence clearly demonstrated the wife was a competent and caring mother. On appeal, the court ruled that the trial judge erred mainly because he was offended by the fact that the wife was living with her divorce lawyer at the time of the hearing. ${ }^{18}$ In In re Charges of Unprofessional Conduct Against Respondent, ${ }^{14}$ a client, who had been romantically involved with the Respondent lawyer seven years before, came to see the lawyer for the purpose of obtaining a divorce. After the initial appointment, but later the same day, the lawyer and client met again for purposes of sexual intercourse. Normally, in a divorce action a divorce lawyer can be quite certain that the client is in a vulnerable state but in this case it was established that the client, unknown to the lawyer, had already had emotional problems and that the sexual involvement with the lawyer contributed to the collapse of her emotional well-being. Nevertheless, the lawyer was allowed to continue practising but placed on two-year probation. In both these American cases, it was the client who suffered adverse effects of the sexual relationships with her lawyer.

On the other hand, another American case illustrates the unpredictable effects that a lawyer can experience from a sexual relationship with his client. In the case of In re: Frick, "11 a highly respected lawyer became romantically entangled with his client and subsequently separated from his own wife and began living with his lover-client. Within a year the torrid relationship soured when the lawyer discovered that his mate was romantically involved with other men on a regular basis. Thereafter, the lawyer conducted himself more as a jealous lover than a respected lawyer. He started harassing his former

(1978). 58.3 P.2d 1157 (Oregon C.A.).

Supro note 8 at 612 .

State of Minn.. Respondent's name struck due to the law on confidentiality; Order tiled September 2. 198.5.

(1985). 694 S.W.2d 473 (Miss. S.C.). 
client, wrote threatening letters and vandalized her property. The lawyer was disciplined, but this case shows that not only do clients need protection from exploitation in sexual relations but also that the lawyers themselves can be unprepared and affected in unforeseeable ways causing loss of independent professional judgment.

The preceding cases clearly show lawyers breached both the fiduciary duties owed to their clients and the spirit of their professional code of ethics. To illustrate further, in his article "Sex and the Divorce Lawyer,"2t Lawrence Dubin offers hypothetical scenarios where sexual involvement between a divorce lawyer and client are likely to breach a lawyer's fiduciary duties, specifically, the duty to avoid conflicts of interest.

Dubin's first scenario contemplates a lawyer who has become sexually involved with his divorce client and in order to prolong the sexual encounters he procrastinates getting through the divorce process. In this instance the lawyer's personal interest to sustain the sexual activity subverts his professional duty to act diligently and efficiently. This potentially conflicts with the loyalty he should have for the client's legal interest which is to get through the divorce as soon as possible. Further, assume that the lawyer realizes the relationship with the client is disappointing and he wants to discontinue it. Hence, he avoids contacting the client in hope that the client will pursue the legal matter somewhere else. Again, the lawyer has breached his ethical duty to advise the client properly, as well as to perform legal services for the client conscientiously, diligently and competently. Alternatively, assume the client had contemplated reconciliation with her husband but the husband subsequently finds out that his wife was having an affair with her lawyer. It is easy to understand that a typical reaction of the husband may be to call off reconciliation. to contest custody declaring that his wife is an unfit mother and generally to make the process a very costly affair when it might have been an uncontested divorcc. Thus, the lawyer's personal interest in sexual expression was in conflict with his client's best interests. Another way in which a lawyer may jeopardize his client's interest is by being called as a witness against his client. It is plausible, the court could deem that information provided by the client to her lawyer was passed while her lawyer was acting in his capacity as lover and not as her lawyer and is, thercfore, not protected by lawyer-client privilege. ${ }^{22}$

Reflecting upon the potentiality of his preceding hypothetical scenarios, Dubin concludes that a prohibitive rule is warranted when one considers the nature and gravity of the harm caused by lawyer-client sexual relationships and the frequency of its occurrence. 33

\section{INEFFECTIVE LEGISLATIVE LANGUAGE AND PROFESSIONAL CONDUCT COMMENTARIES}

The American and Canadian statutory provisions used by the law societies to define the concept of conduct unbecoming are vague and neglect to express any prohibition on 
lawyer-client sexual relationships. In Canada. compared to other provinces, Alberta provides one of the most descriptive definitions of conduct unbecoming found in the Legal Profession Act of Alberta: ${ }^{2+}$

$47(1)$ leor the purpones of this $\Lambda$ at. any conduct of a member. arising from incompelence or otherwise. that

(a) is incompatible with the best interests of the public or of the members of the Socicty, of

(b) tends to harm the standing of the legal profession generally. is conduct deserving of sanction. whether or not that conduct relates to the member's practice ats a harrister and solicitor and whether or not that conduct cxcurs in Altherta.

To assist in the interpretation of the legislative delinition of unbecoming conduct, the Codes of Professional Conduct (published by the Law Society of Alberta and the CBA) include commentaries on ethical responsibilities outlined in the rules. Some of the CBA's commentaries on the rules that attempt to describe conduct unbecoming a lawyer are as follows: integrity of the profession will be compromised when a lawyer's conduct in his personal life or professional activities is dishonourable or impairs a client's trust in the lawyer's abilities." To prevent prejudicing a client's interests a lawyer should avoid conflict of interests or compromising influences which could hamper the lawyer's judgment and frecdom of action. ${ }^{26}$ As a result of the lawyer's position in the community, he is held to a higher standard of responsibility than that of a private citizen. ${ }^{27} \mathrm{He}$ must neither subvert the law nor do anything which lowers the public's confidence in the administration of justice and the legal system. This also means that each individual lawyer should strive to avoid irresponsible conduct and appearances of impropriety which may crode public respect and trust in the legal profession. ${ }^{2 x}$

R.S.A. 1981), c.L-9. The Ontario and British Columbia provisions on conduct unbecoming provide only a statement that such conduct is sanctionable but fail to elaborale at all on what unbecoming conduct is.

In Ontario The Len Societr Act. R.S.O. 1980), c.233 provides:

34. If a member is found guilty of professional misconduct or of conduct unbecoming a barrister und solicitor after due investigation by a committee of Convecation. Convocation may by order cancel his membership in the Sociely by disbarring him as a barrister and striking his name off the roll of solicitors or may by order suspend his rights and privileges as a member for a period to be named or may by order reprimand him or may by order make such other disposition as it considers proper in the circumstances.

In British Columbia the Legal Professions Act, R.S.B.C. 1979, c.26 provides:

48. By direction of the Benchers, or on the application of any person, or of its own motion. the Discipline Committee may, whether a complaint is made or nol, inquire whether any member of the Society has been guilty of

(a) misappropriation or wrongful conversion by him of moncy or other property entrusted to or received by him in his capacity as a member of the Society: or

(b) other professional misconducl; or

(c) other conduct unbecoming a member of the Sociely; or

(d) a breach of this or any rules made under it.

Supra note 12. Chapter I. Commentary $\$ 2$ at 1.

Ibid. at Chapter V. Commentary \#1 at 17.

Ibid. at Chapter XIl. Commentary \#3 at 5.3.

lbid. at Chapter XIX. Commentary \#I and \#10 at $81-83$. 
Despite all these commentaries which refer to different aspects of a lawyer's conduct, it is unfortunate that none refers specifically to prohibiting or qualifying lawyer-client sexual intimacies. Based on the possible interpretations of 5.47 of the Legal Profession Act of Alberta and interpretations of the CBA commentaries, any definition of conduct unbecoming a lawyer is a matter of degree measured on a sliding scale. But, due to the absence of an express rule prohibiting or qualifying lawyer-client sexual relationships, the question is where along the sliding scale do lawyer-client sexual relationships fall. It is suggested that the sliding scale and legislative language are wide enough to embrace lawyer-client sexual involvement, but the determination of ethical or moral conduct unbecoming a lawyer is often an arbitrary decision which is mainly to be taken by the particular benchers sitting on the disciplinary committee. Chosen from the benchers of each law society, a member sitting on the disciplinary committee may lack impartiality due to the fact that he may be a close friend of or a lawyer whose practice enjoys financial benefit of business references from the lawyer who is before the disciplinary committee. In other words, the strictness of the disciplinary committee's sanction may be dependent upon its members' association with the lawyer to be disciplined, its attitude towards the issue of lawyer-client sexual involvement, and its understanding of the seriousness of the harm that can befall the client as a result of that involvement. Perhaps if there were an explicit provision for a rule prohibiting lawyer-client sexual intimacies this could provide the discipline committee with an objective benchmark position from which exceptions can be made where warranted.

Another drawback of the absence of an express prohibition of lawyer-client sexual relations is that lawyers attempt to make technical arguments and assert questionable defences. One defence might be that there was no intention to conduct oneself in a manner unbecoming a lawyer. Another defence might be that the client waived the lawyer's obligation to represent the client's best interest in favour of engaging in sex, in other words, that the client participated willingly in the affair. ${ }^{2 y}$ However, due to the client's likely emotional vulnerability and dependence upon the lawyer, it is unlikely that this could be considered a meaningful waiver. Yet, another defence might claim that sexual involvement between lawyer and client was not expressly proscribed in the professional conduct rules and therefore discipline would be inappropriate without some advance notice that the involvement was unethical. ${ }^{31}$

To rebut these defences and justify that the unbecoming conduct arising out of a lawyer-client sexual relationship warrants disciplinary measures the courts and disciplinary committees are compelled to stretch the concept of fiduciary duties and apply a liberal interpretation to the commentaries on the rules.

Supra notc 8 al 613. Also Deinick v. Frid (Ott. 21. 1991). O.J. No. 1803-1129-009A. (Ont. Court of Justice General Division) where court held that a plaintiff's consent to participating in an affair is irrelevant where the fiduciary had exploited his position of trust to oblain consent. However, in some circumstances the willing participation of a client may be mitigating on damages. Supra note 8 at 611. 


\section{A. INEFFECTIVE SANCTIONS IMPOSED BY DISCIPLINARY COMMITTEES}

In Canada, the provincial legislatures have entrusted to the law societies, as self-governing bodies, the responsibility for setting the standards of professional conduct and for disciplinary actions of the legal profession. Most law societies have modelled their standards of professional conduct upon the standards recommended by the CBA." As a means of upholding the integrity and ethical standards of the profession, the provincial law societies are empowered to discipline their members for professional misconduct and conduct unbecoming a barrister and a solicitor. However, as the above mentioned cases show, the type of sanction or discipline rendered against the offending lawyers have been penalties of only nominal proportions, such as private and public reprimand and two-year probation with the right to continue practice or one-year suspension. ${ }^{32}$

The problem with these nominal sanctions is that they communicate a variety of incorrect messages to the profession and the public. First, that discipline committees lack an understanding of the potential harm that lawyer-client sexual relationships can cause to the parties, the profession and the public's respect for the administration of justice. Second, that cursory treatment of complaints shows a lack of respect for the victims and this trivialization will discourage other future complainants or encourage civil action for breach of fiduciary duties. Lastly, the lack of meaningful sanctions neither nurtures lawyers of good character nor fosters public respect.

Considering the impact that a lawyer-client sexual relationship can have on the client's interests and on the private lives of both parties, the damage to the reputation of the profession, the administration of law and justice as a whole, it seems advisable to give notice to lawyers that sexual expression with clients is off limits. In both the United States and Canada, in the absence of any express rule prohibiting sexual relations between lawyers and their clients, the court has addressed this dilemma only reluctantly. The court is hesitant to legislate judicially but it has an overriding responsibility to safeguard the legal institutions in society when the self-governing bodies fail.

In the Canadian case of Szarfer v. Chodos, ${ }^{33}$ Mr. Chodos obtained confidential information about his client's, Mr. Szarfer, impotence and matrimonial difficulties. Promptly thereafter, Mr. Chodos used this confidential information to his personal benefit by initiating an affair with Mrs. Szarfer. Upon discovering the affair, Mr. Szarfer suffered a traumatic emotional disorder. 
The court found that, as a fiduciary, Mr. Chodos had breached his ethical duty of client confidentiality by using the confidential information to the disadvantage of his client: ${ }^{.4}$

The fiduciary relationship between a lawyer and his client forbids a lawyer from using any confidential information ubtained by him for the bencfit of himself or a third person or to the disadvantage of his client. The crucial question for decision is whether or not the defendant used confidential information for his own purposes or to the disadvantage of the plaintiff. The highest and clcarest duty of a fiduciary is to act to advance the bencficiary's interest and avoid acting to his detriment. A fiduciary cannot permit his own interest to come into conflict with the interest of the beneficiary of the relationship... I am satisficd that he used confidential information tor his own purposes in order to obtain the delights and benctits of the affair.

Even though the court found $\mathrm{Mr}$. Chodos civilly liable for damages over $\$ 43,000$, the Law Society of Upper Canada by way of sanction only reprimanded him publicly.

Another examplc of breach of confidentiality within a fiduciary relationship is the recent Canadian decision, Deiwick v. Frid. ${ }^{35}$ Apparently this case is the first to hold a parish minister liable for breach of fiduciary duty for sexual improprieties. In this case Mr. Frid, parish minister, acted as marriage counsellor to Mr. and Mrs. Deiwick. After marriage counselling proved unsuccessful the parties separated. Within two weeks of the separation Mr. Frid and Ms. Deiwick became involved in a sexual relationship. This relationship lasted for approximately four years and when Ms. Deiwick realized that Mr. Frid's promise to leave his wife and the church would never be fulfilled, she brought an action for breach of fiduciary duty causing emotional and mental distress. Mr. Frid's counsel argued that because Ms. Deiwick participated willingly there was no unilateral exercise of power over Ms. Deiwick and, therefore, no existence of a fiduciary relationship to be breached. Mr. Justice Craig, the judge hearing the case, rejected this argument and instead found that although Mr. Frid did not contribute to the marriage breakdown, he exploited his position of trust and confidence by using confidential information for his own benefit to foster a sexual relationship with Ms. Deiwick. In other words, the court was not as concerned that the beneficiary in a fiduciary relationship consented or participated willingly, but more concerned with how the fiduciary misused confidential information to induce the beneficiary's participation. In addition, Mr. Justice Craig held that a fiduciary obligation did not terminate for a marriage counsellor once the marriage counselling stopped. This finding presumably applies to other fiduciary relationships such as corporate directors, who still have a fiduciary obligation once their relationship with the company is severed and lawyers, who still have a duty of confidentiality and a duty to avoid conflict of interest after their retainers have terminated. ${ }^{\text {3h }}$

Ihid. al 676. The (Ontario Cour of Appeal. (1989). 66 ().R. (2d) 350). dismissed the appcal citing that the trial judge s lindings were supported by the cvidence. Further, the appeal court found there was no reasen in principle why the disadvantage or loss to the client must he of a commercial or business naturc.

34. "Minister's Sex With Parishioner Breached Fiduciary Duty" The Lawyers Weekly 122 Nowember 1991) 4. A comment on implications of the Deiwich v. Frid case. 
A brief glance at some American cases reveals that the U.S. courts have also had to address the same issue of lawyers exploiting their fiduciary position to engage in sexual activity with clients. In re: Wood,,$^{37} \mathrm{Mr}$. Wood, a lawyer, was suspended for one year when it was discovered that in lieu of payment from his financially constrained client, he demanded and received nude pictures of his female client and her daughter, and he had sex with the mother. In defining that that conduct was unbecoming of a lawyer, the court found that it had to impose some sanctions even though there was no express rule prohibiting lawyer-client sexual relationships: ${ }^{3 \times}$

\begin{abstract}
This court has not previously addressed misconduct as found in this proceeding. It should be readily understood at the outset. that this Coun does not, cannot, and will not attempt to establish guidelines for the sexual activities of the members of the bench and bar. Yct, this court, under the Constitution of the State of Indiana. is given the responsibility of the preservation of the integrity of the judicial system and its officers, and when the sexual activities of an attorney involve conduct which demonstrates an unfitness to practice law, this coun has no alternative but to meet its responsibility and impose disciplinc. if approprialc.
\end{abstract}

Ten years after his first suspension, Mr. Wood was back betore the Indiana Supreme Court. This time in lieu of financial payment he took the nude pictures of one of his clients and her niece. He demanded that oral sex be performed upon him by the aunt and niece and also that the niece make a pornographic movie for him to watch. That time, in light of the Indiana State Bar's failure to adopt an express rule prohibiting lawyer-client sexual relations, the court relied on four separate Professional Code provisions to support its ruling to disbar Mr. Wood for breach of fiduciary duties and unbecoming conduct. ${ }^{39}$

In another American case, Barbara A. v. John G. ${ }^{\text {t1 }}$ a client brought a civil suit against her lawyer for misrepresentation of his sterility. She became impregnated as a result of their sexual involvement, and suffered bodily injury as well as permanent sterility when surgery was required because of an ectopic pregnancy. Rather than judicially adopting a rule proscribing sexual relations between lawyer and client, the California appellate court held that the lawyer was civilly liable for breaching his fiduciary capacity by exerting undue influence over his client. In doing so, the court stated that the question of prohibition on lawyer-client sexual relations is a question more appropriately directed to the California State Bar."

From the preceding cases it is evident that both the American and Canadian courts recognize that problems can arise as a result of lawyer-client sexual relationships. However, the law societies in both countries ${ }^{32}$ have failed to adopt an express rule

(1976). 358 N.E.2d 128 (Ind. S.C.).

Ihill. all 1.33 .

In re: Woed (Ind. 1986), 489 N.F.2d 1189 at $11(9)$ (Ind. S.C.).

(1983). 19.3 Cal. Rptr. 422 (Calit. C.A.).

Ihill. all 4.3.3.

A growing number of state hars and provincial law sexietiess are lutking about studying such a rule but only recently has the California State Bar approved a rule prohihiting lawyer-client sexual relationships. 
prohibiting lawyer-client sexual relationships. In addition, the disciplinary committees of the law societies in both countries typically appear to favour nominal sanctions in instances of client victimization in a lawyer-client sexual relationships. Reluctantly and depending on the perceived injustice. courts in both countries intervene to attach civil liability to the lawyer who, in victimizing his client, is deemed to breach his fiduciary obligations to his client.

Though some courts have strongly suggested that the law societies should address the issue of a lawyer's sexual relation with his client, only the American courts have shown a willingness, on rare occasions, to usurp the state bar/law society's traditional role of a disciplinarian. On the other hand, the courts in Canada take a hands-off approach and stop short of performing the disciplinary functions normally reserved to the self-governing Law societies.

Due to the courts reluctance to intervene, there is a void in the disciplinary process for which the real responsibility to fill rests with the American state bars and Canadian provincial law societies. Continued failure of the self-governing bodies of the legal profession to properly address the void may result in a greater willingness of the courts to play a larger role in disciplining members of the legal profession. Law societies and statc bars could fill this void by introducing clearer language prohibiting or qualifying lawyer-client sexual conduct and reinforcing the substance of the language with stiffer sanctions than those now being issued by the disciplinary committees.

\section{REGULATION OF SEXUAL INVOLVEMENT WITHIN FIDUCIARY RELATIONSHIPS}

In his article. "Fiduciary Law," ${ }^{4+3}$ T. Frankcl identifies two characteristics of a fiduciary relationship which increase the risk of abuse of trust. The first is the substitution of the fiduciary to perform a service in place of the entrustor. The second characteristic is that the fiduciary "obtains power from the entrustor... for the sole purpose of enabling the fiduciary to act effectively." ${ }^{\text {th }}$ Thus, the essence of a fiduciary relationship is one in which the partics do not deal on equal terms. The more power that an entrustor must grant to the fiduciary to receive the intended benefit of the service performed, the more unequal the terms of the relationship and the more vulnerable the trusting individual becomes to abuse of that authorized power. ${ }^{+5}$ Therefore, legal controls and regulations are imposed on fiduciary relationships 10 reduce the risk of abuse of trust.

Many professions involving a fiduciary relationship have displayed an awareness of and responsibility for regulating fiduciary sexual involvement by adopting express rulcs proscribing sexual relations between the fiduciary and client. For example, many sectors of the medical profession in the United States have codes of professional conduct which

"T. Frankcl, "Fiduciary Lalw" (1983) 71 Cal. L.. Rev. 795.

$+\quad$ Ibicl. at $8(x)$.

" L. Jorgenson \& R.M. Randles, "Time Out: The Statute of Limitations and Fiduciary Theory in Psychotherapist Sexual Misconducl Cases" (1991) 44 Oklahoma I.. Rev. 181 at 197. 
expressly forbid sexual relationships with patients. ${ }^{\text {th }}$ In Canada, sectors of the medical profession have adopted a similar position to that in the United States. Both the Medical Profession Act, R.S.A. 1980, M-12, s. 34 and the Occupational Therapy Profession Act, R.S.A. 1990, O-2.5, s. 28, declare that conduct that is detrimental to the best interests of the public, whether or not that conduct is disgraceful or dishonourable, may constitute conduct unbecoming of the profession in the judgment of the disciplinary committee. This type of general statement sounds much like the policy statements in the code of professional conduct handbooks of the law societies. However, the bylaws of the respective medical associations add substantive content to the legislation and provide the disciplinary committees with a clear direction for handling complaints of sexual impropriety or abuse of trust within fiduciary relationships. ${ }^{47}$

As between certain medical professional-patient relationships and divorce lawyer-client relationships principles in the case law suggest there are many similarities in fiduciary obligations. For example, in Parfit v. Lawless, the court points to the similarities in fiduciary obligations of physicians and lawyers: ${ }^{48}$

... T The medical practitioner. like the lawyer or other professional advisor. is bound... in see to it that in no circumstance will he allow his professional duty to come into conflict with his personal interests.

\section{Likewise, in Henderson v. Johnston, LeBel J. drew a similar comparison of fiduciary} obligations between physicians and lawyers: ${ }^{49}$

The legal relationship between a patient and his physician or surgeon ... is clearly established ... that it is fiduciary and confidential. It is the same relationship as that which exists in equity between a parent and his child. a man and his wife, an attorney and his client, a confiessor and his penitent and a guardian and his ward.

For example, the American Psychiatric Association has an annotuted book of principles of medical ethics which expressly states:

2 IT/he necessary inlensity of the therapeutic relationship may tend to activate sexual and other needs and lantasies on the part of both patient and therapist, whilc weakening the objectivity necessary lor control. Sexual activity with the patient is unethical.

The American Psychologists Association has a similar hook of ethical principles declaring a like prohibition:

6(a) Psychologists are continually cognizant of their own needs of their potentially influential position vis-a-vis persons such as clients, students, and subordinates. They avoid exploiting the trust and dependency of such persons....scxual intimaties with clients are uncthical.

„ Canadian Medical Association. Code of Eirhics 1990. Commentaries on responsibilitics to the patient require that:

3. An ethical physician will practice in a fushion that is above reproach and will lake neither physical. emotional nor financial advantage of the patient.

Altherta Assuciation of Registered Oecupational Therapists. By-laws 1990. Code of Conduct commentaries on responsibility to the client require that:

3. $|A| n$ occupational therapist and restricted practitioner will ensure that his conduct in the practice of his profession is above reproach, and that he will take neither physical, emotional nor financial advantage of his client. 
By examining the purpose of these fiduciary relationships and the possible consequences that abuse of trust might bring it is possible to draw the conclusion that lawyers and physicians have been entrusted with the same degree of power by the client I patient to provide the intended benefit of the service. ${ }^{31)}$ Both the legal and medical professions often involve the client / patient revealing intimate and personal information of which the lawyer / medical professional is the recipient. The recipient is also responsible for not exerting any undue influence in using the information for his personal interests. For this reason lawyers should be held to a similar high standard as that of the medical professionals not to exploit their client's property and person.

In Canada. a Task Force on Sexual Abuse of Patients, set up by the College of Physicians and Surgeons of Ontario, released its preliminary report in late May 1991, and its final report in late November 1991. The College immediately adopted the Task Force's recommendation of the principle of "zero tolerance." Under zero tolerance there are two levels of sexual offences: sexual impropriety and sexual abuse. The former would be a lesser offence and encompasses inappropriate sexual comments and procedures that reflect a lack of respect for the patient's privacy. The latter, a more serious offence, involves any sexual, or that which may be interpreted as sexual, conduct with a patient. ${ }^{51}$ An offender in the latter level would warrant a fine and permanent removal of a physician's licence to practice unless a strong case could be made that there were good prospects for rehabilitation of the physician. ${ }^{52}$

After having released its preliminary report, the Task Force was highly critical of the Law Society of Upper Canada disciplinary committee for imposing a suspension of only 12 months against Mr. Coccimiglio. Based on the disciplinary decision made about Coccimiglio, Pat Marshall, one of the members of the Task Force, commented that it was evident that the Law Society failed to understand that the incident involved a serious breach of client trust. Ms. Marshall's comments may be accurate with respect to the Law Society but the zero tolerance rule may not withstand a challenge under the Canadian Charter of Rights and Freedoms ${ }^{53}$ or scrutiny under the principles of administrative law. Application of the zero tolerance rule to the Coccimiglio case would have placed Mr. Coccimiglio in the sexual abuse level, therefore, demanding that he be disbarred. But if such a penalty automatically attached to this categorical offence as a matter of policy, it would usurp the disciplinary committee's discretionary power to make decisions which are based on consideration of all the relevant surrounding facts. Likewise, a blanket prohibition of lawyer-client sexual relationships might give rise to a Charter challenge, such as infringing on onc's right to freedom of association and, arguably, a restriction on one's right to choose a lawyer. However, the prohibition may be a reasonable limit on rights and freedoms which is demonstrably justified under section I of the Charter.

Supra note 4.5 at 198.

College of Physicians and Surgeons of Ontario. Task Force on Sexual Abuse of Patients, 1991.

Supra noic 16 al 1.

Canudian Charter of Rights and Freedoms. Part I of the Constitution Act. 1982. being Schedule B of the Camada A(') 1982 (U.K.). 1982. c. II [hereinafter Charter]. 


\section{PREVENTATIVE SUGGESTIONS}

As a step in the right direction, the State Bar of California approved a rule prohibiting most sexual relationships between lawyers and their clients in April 1991. It is the first rule of this kind in the United States and is laid out as follows in the Califomia Rule of Professional Conduct 3-120 (Sexual Relations With Client):

(A) For purposes of this rule. "sexual relations" means sexual intercourse or the touching of an intimate part of another person for the purpose of sexual arousal, gratification. or abuse.

(B) A member shall not:

(1) Require or demand sexual relations with a client incident to or as a condition of any professional representation; or

(2) Employ coercion, intimidation, or unduc influence in entering into sexual relations with a client: or

(3) Continue representation of a client with whom the member has sexual relations if such sexual relations cause the member to perform legal services incompetently in violation of rule 3-110.

(C) Paragraph (B) shall not apply to sexual relations between members and their spouses or to ongoing consensual sexual relationships which predatc the initiation of the lawyer-client relationship.

(D) Where a lawyer in a firm has sexual relations with a client but does not participate in the representation of that client, the lawyers in the firm shall not be subject to discipline under this rule solcly because of the occurrence of such sexual relations.

(E) A member who engages in sexual relations with his or her client will be presumed to violate rule 3-120. paragraph (B)(3). This presumption shall only be used as a presumption affecting the burden of proof in disciplinary proceedings involving alleged violations of these rulcs. "Presumption affecting the burden of prool" means that presumption defined in Evidence Code sections 605 and 606.

Although the State Bar of California adopted the rule, Robert Talcott, its Vice President, believes that the previous ethical rules of the bar might have been interpreted to include sexual relations between a lawyer and client as behaviour subject to disciplinary action by the state bar. Talcott states that the rule is "a victory for public protection" but adds that the rule "speaks the obvious and any responsible lawyer knows this." rationale of this comment, when applied to the medical profession, would be to suggest that physicians, psychiatrists, occupational therapists, and others, are not as responsible as lawyers and, therefore, they need a rule proscribing sexual relations between them and their patients. This suggestion seems ludicrous as lawyers, like physicians, are in a fiduciary relationship and, therefore, should be held to the same high standard of care and responsibility.

In the United States, the rule against lawyer-client sexual relationships adopted by the California State Bar has become a starting point to address the whole issue of lawyer-client sexual relationships. Apart from prohibiting lawyers from demanding sex from a client as a condition of payment ${ }^{55}$ or using intimidation or undue influence to start a sexual relationship with a client, ${ }^{5 h}$ paragraphs $(B)(3)$ and (E) of the California 
Rule of Professional Conduct 3-120 stress that if a lawyer and client voluntarily enter into a sexual relationship and the client subsequently complains then there is a presumption that the sexual involvement adversely affected the performance of the legal services. This presumption can be rebutted if the lawyer can show that the relationship did not affect the quality of legal services. Paragraph 3-120 (C) provides another exception to the rule when lawyers represent their spouses and those with whom the sexual relationship predated the legal representation.

Although the adoption of the California State Bar rule 3-120 could be a step forward for Canada, it would be imprudent to adopt this rule fully. The problem with this rule is that it focuses only on the competent performance of legal services but ignores the other purposes of the rule. such as: the prevention of client victimization and the lawyer's responsibility to maintain the integrity of the profession and foster public respect for the adminstration of justice and the legal system.

In Canada, the legal profession has not yet adopted any policy or rules to expressly prohibit or qualify lawyer-client sexual relationships. Instead, the law societies seem to show concern only when a lawyer abuses his fiduciary relationship by misusing a client's monies and property held in trust. An indicator of this primary concern is clearly evident from a survey of the two-volume set of synopses of disciplinary cases compiled for the Law Society of Upper Canada by S.E. Traviss. ${ }^{57}$ Of the 254 disciplinary cases mentioned as being considered by convocation between 1972 and 1984, $13 \%$ of the complaints were on the basis of conduct unbecoming. Of the cases concerning conduct unbecoming the convocation sanction imposed was $14 \%$ reprimand. $19 \%$ suspension and $67 \%$ disbarment. Of the preceding cases only 1 was related to sexual impropriety or sexual abuse. The majority, $87 \%$, of the complaints were grounded on professional misconduct and were primarily concerned with abuses of client's property and trust accounts and misappropriation of their client's monies. The convocation sanction of the professional misconduct cases resulted in $65 \%$ disbarment. $9 \%$ suspension and $26 \%$ reprimand.

The relatively low number of complaints about sexual impropriety or sexual abuse complaints suggests there is no problem in Canada. However, it excludes the unreported number of clients who fail to complain, an issue which has only recently begun to gain attention in the United States. ${ }^{5 x}$ Although the law societies in general are willing to take measures to protect the client's property and trust monies, they neither acknowledge nor

S.E. Traviss, Symopsess of Disciplinary Cases Considered by Convocation 1972-1984, vol. I and 2 (Toronto: Law Society of Upper Canada, 1985).

Supra note 8 at 589. A recent survey in the United States indicates that considerably more sex between doctor and patient exists than most people would have believed. See "Psychiatrists Seldom Report Others" Abuses" Detroit Free Press, (8 April 1987) at 7a. col. 5. Dr. Nannette Gatrell, a psychiatrist at Boston's Beth lsracl Hospital, reports that $65 \%$ of psychiatrists responding to a questionnaire reported having treated patients who had been sexually involved with a previous therapist. Eighty-seven percent of those patients had indicated that the sexual cncounters were harmful to them. The abuse was reported in less than $10 \%$ of the cases. It should also be nuted that as of January 1987. four cases of sexual impropriety between lawyer and client were being prosecuted by the State of Maine. This number of prosecutions in such a small state provides some evidence that the problem of lawyers engaging in sexual intimacies with clients is a real une. 
give notice of prohibiting or qualifying lawyer-client sexual relationships. ${ }^{59}$ This is a fault and shows a lack of understanding of the seriousness of the breach of fiduciary obligation. Perhaps, a lawyer should be held to show the client the same high standard of trust in caring not to exploit her emotions and person as not to exploit her money and property. Yet, to suggest elevating the standard of trust in dealing with human emotions to a level of importance only equal to that of property and money can be interpreted as degrading for a victim and can signify the trivialization of human emotions and feelings.

To address some of these concerns, a suggested rule for governing lawyer-client sexual involvement might state that when a lawyer and client wish to enter into a sexual relationship voluntarily then the lawyer is required to withdraw from legal representation and make arrangements to transfer the legal services to another law firm. Still, it can be argued that a lawyer can manoeuvre around this rulc by abstaining from sexual involvement while completing legal representation in the matter. Upon completing the legal representation the lawyer, armed with the confidential information gained through the fiduciary relationship, could then pursue the client. It is conceivable that during the legal representation the lawyer, while entertaining thoughts of pursuing the client after legal representation, could still undermine the client's best interest in favour of his own interests. For cxamplc. he may encourage situations in which his client becomes very emotionally dependent on him. Likcwise, it is probable that a lawyer who has withdrawn from legal representation can still indirectly interfere with the client's best interests but this interference may be mitigated to a degree if the client is recciving independent legal representation. Accordingly, whether a lawyer withdraws from legal representation or completes legal representation and then pursues sexual involvement with the ex-client, it seems appropriate to suggest that there is a need for a cooling-off period between ceasing legal representation and beginning sexual involvement. However. enforcing a cooling off period seems nearly impossible to regulate.

The use of confidential information by the lawyer to pursue the "benefit" of a sexual relationship with a vulnerable client is analogous to a lawyer's pursuit of monetary benefit based on confidential information he gained from a commercial client. A lawyer will be in violation of the confidentiality rule by using the confidential information of the client's business and affairs for the benefit of him or a third party or to the disadvantage of the client. ${ }^{(x)}$ Even after legal representation has ceased the lawyer is prohibited from using the confidential information for his benefit. There is an implied requirement of a waiting period before the lawyer could use the confidential information to make investments. whereby the intervening market forces will act on the confidential investment so that he will be in no better position than the average buyer and seller in the market. What is the required waiting period after a lawyer withdraws his legal services in the divorce process before the "market forces" neutralize the lawyer's confidential information about the client? Realistically, emotions and personal involvement do not conform to the principles be used to pay damages to clients who have been sexually abused or manipulated by lawyers exploiting their positions of trust and confidence. 
of business and economics, therefore, the required waiting period will vary from case to case. However, the underlying principle is that the rules of confidentiality and fiduciary obligation, whether in divorce or commercial law context, do not terminate simply because legal representation ceases."

On the other hand, to suggest total prohibition on lawyer-client sexual relationships in any context or circumstances appears too restrictive. It is feasible that a lawyer-client relationship can become a personal long term relationship that realizes both the client's and the lawyer's best interests. In these instances two people should not be denied the happiness that comes from such relationships.

However, if every client seeking a divorce is a potential sexual partner then there should be some strict regulations in order to discourage the lawyer from taking advantage of vulnerable clients. Likewise, there should be a high standard on the lawyer to ascertain that reconciliation was not an option for his female client and her spouse.

\section{CONCLUSION}

Without trust the lawycr-client relationship would cease to exist. All interaction and disclosure between a lawyer and his client is within the scope of a fiduciary relationship and occurs premised on the guarantee of trust that in no way will the lawyer use the information to his advantage nor to the disadvantage of his client. Therefore, in a fiduciary relationship a client has a right to expect that this guarantee of trust extends to prevent any misuse of her person as well as of her property and money. It is unacceptable that a lawyer, as a fiduciary, would use confidential information as a means to induce his client's participation in a sexual relationship. In this situation a client can be easily exploited emotionally and monetarily resulting in the erosion of the trust, the whole essence and reason for the existence of any fiduciary relationship.

Nevertheless, the impact of the abuse of trust in a lawyer-client sexual relationship is not confined to that single lawyer-client relationship; it affects other parties, such as the public and the legal profession. Not only is a single lawyer's reputation ruined but in the eyes of the public the unbecoming conduct erodes the legal profession's respectability: ${ }^{62}$

Above all. Ict's remember that cthics and prolessional integrity are much like romance. Once lost. they are never regained. Hence. the importance of guarding against that loss. Our reputations are the nust intportant asset we have.

The contribution of the law socictics in this situation can be to assist clients and lawyers to avoid these problems if they identify with greater certainty what conduct is unbecoming and what is not. By providing such assistance, the law societies would help their members fulfil the overall goals of their profession, such as to guarantee competent 
legal services to clients, to maintain the integrity of the legal profession and to foster public confidence in and respect for the administration of justice.

In the absence of an express rule proscribing lawyer-client sexual relationships it is time to challenge the presumption that the highest ethical conduct will always prevail in lawyer-client relations. From the vulnerable client's perspective the fiduciary basis for the protection of her interests should be entrenched in the rules of professional conduct. An express rule that proscribes lawyer-client sexual relationships should make it clear that a lawyer breaches his ethical duty when he uses the fiduciary relationship as a vehicle to manoeuvre his client into a sexual relationship by misusing the information obtained from her based on the presumption of trust. 